\title{
Morphological identification and prevalence of hard ticks (family; Ixodidae) in cows at district Pishin, Baluchistan Pakistan
}

Kiran Iqbal ${ }^{1}$, Nosheen Rafique ${ }^{1}$, Aasia Karim ${ }^{1}$, Ambreen Ijaz ${ }^{1}$, Muhammad Kamran Taj ${ }^{2 *}$, Asmatullah Kakar ${ }^{3}$, Zaib-Un-Nisa Hanif ${ }^{1}$, Saqiba Bibi ${ }^{1}$, Gulshan Ghafoor ${ }^{1}$, Ayesha Ghafoor ${ }^{1}$ and Muhammad Shafiq ${ }^{4}$

1. Department of Zoology, Sardar Bahadur Khan Women University Baluchistan Quetta-Pakistan

2. Center for Advanced Studies in Vaccinology and Biotechnology, University of Baluchistan, Quetta-Pakistan

3. Department of Zoology University of Baluchistan, Quetta-Pakistan.

4. Department of Commerce University of Baluchistan, Quetta-Pakistan

*Corresponding author's email: kamrancasvab@yahoo.com

Citation

Kiran Iqbal, Nosheen Rafique, Aasia Karim, Ambreen Ijaz, Muhammad Kamran Taj, Asmatullah Kakar, Zaib-UnNisa Hanif, Saqiba Bibi, Gulshan Ghafoor, Ayesha Ghafoor and Muhammad Shafiq. Morphological identification and prevalence of hard ticks (family; Ixodidae) in cows at district Pishin, Baluchistan Pakistan. Pure and Applied Biology. Vol. 10, Issue 1, pp272-279. http://dx.doi.org/10.19045/bspab.2021.100028

Received: 23/06/2020 Revised: 24/08/2020

Accepted: $25 / 08 / 2020$

Online First: 17/09/2020

\section{Abstract}

The present work was conducted on various aspects of tick prevalence in different breeds of cows at District, Pishin. The research trial revealed a high prevalence of tick infestation in cows at District, Pishin. A total of 200 cows including from different breeds of varying age was observed. Total prevalence was observed as $29 \%$ in different breeds of cows (Sindhi, Sahiwal, Tharparkar, American, and Austrian). In male cows, the prevalence was noted as $33 \%$ and in female cows, the prevalence was $25 \%$. Males were found to be more infested than females. A total of 443 numbers of ticks were observed in various parts of the body. Prevalence was $45.59 \%, 27.53 \%, 13.76 \%, 8.80 \%$ and $4.28 \%$ in-ear, mammary gland, genital organ, tail, and the body region of cow respectively. Eight species of ticks were identified in the study area including Hylomma anatolicum, Hylomma dromedarii, Hyalomma truncatum, Hylomma scupense, Boophilus annulatus, Dermacentor andaroni, Dermacentor variabilis, and Amblyomma americanum. The male: female ratio was 1:1:1. These findings would be helpful to design applicable and appropriate control measures and prevention to control ticks in cows in the study area.

Keywords: Baluchistan; Cows; Ixodidae; Identification; Prevalence; Pishin; Tick

\section{Introduction}

Ticks are the most common ectoparasites, which are found on different vertebrates in different stages. Almost $80 \%$ of the cattle population of the world is infested by the infection of ticks [1]. Ticks are found in 
moist and warm conditions which help them to undergo metamorphosis [2]. Ticks are divided into two families, Ixodidae (hard tick) and Argasidae (soft ticks). Ixodidae ticks contain 670 identified species and Argasidae has 150 species in the world [3, 4]. Ticks are found on various parts of cows like neck, ear, and belly region $[5,6]$.

Most species of ticks are vectors of many harmful diseases [7], such as Anaplasmosis, Lyme disease, Babesiosis, Thelriosis, Rocky Mountain spotted fever, Crimean Congo hemorrhagic fever, Relapsing fever and $\mathrm{Q}$ fever $[8,9,10]$. Many severe symptoms are reported in the host by tick infestation such as blood loss, stress, toxicosis, tick paralysis, and skin damage in cattle $[11,12]$.

The socio-economic life of people relays mainly on cattle and their by-products. They not only provide meat and milk but also supply hide and skin and help in raised foreign exchange $[13,14]$. All tick requires six weeks to three years to pass through their four life stages i.e. egg, larva, nymph, and adult. Usually, tick required the blood for egg production $[15,16]$. Nymphs left the host body when engorged and find a new host from the environment. In three host species, nymphs changed its host after each molt $[12,17,18]$.

Different studies have been conducted on various aspects of tick prevalence in various parts of the country and from abroad however, similar information from Pishin was lacking. This study aimed to identify different species of ticks on various breeds of cows, to find out their infestation and prevalence in the study area, to improve health status, milk production and meat quality of cows.

\section{Materials and Methods}

\section{Study area and study population}

Baluchistan is the largest province of Pakistan, spreading over an area of 350,000 $\mathrm{sq} / \mathrm{km}$ [19]. This study was conducted at randomly selected livestock farms in the study area. Geographically, District Pishin is located in the Baluchistan Province with coordinates of $30^{\circ} 34^{\prime} 49.01 \mathrm{~N}$ and $66^{\circ}$ 59'46.00 E with an Elevation of 5,102. The area is canal irrigated and heavily populated with livestock.

200 different cows from different breeds (Sindhi, Sahiwal, Tharparkar, American, and Austrian) were randomly selected for study from local farms of Pishin District, Baluchistan to identify and determined the prevalence of hard ticks in different species of cow.

\section{Tick collection and preservation}

Ticks were collected from different parts of the body and examined for specie identification. All parts of the animal body (ear, mammary gland, genital organ, tail, and body) were deeply examined for the presence of the tick. After being separated from the body of the host, ticks were preserved in $30 \%$ alcohol. They were boiled in potassium hydroxide $(\mathrm{KOH})$ solution for 20-30 minutes then removed and passed through a graded level of ethanol $(30 \%$, $50 \%, 70 \%, 90 \%$, and $100 \%$ ). In each grade of ethanol, ticks were kept for 2 hours, before shifting to the higher grade. After $70 \%$ of alcohol, ticks were stained than transferred to $90 \%$ and then $100 \%$ alcohol. Before placing on a slide into Canada balsam, the ticks were dipped in xylol and then clove oil for few seconds.

\section{Tick identification and morphological study}

First, a gross identification of the ticks was performed. As a final step, the ticks were classified into different species depending on their morphology and basic structural characteristics. Such as the shape of the scutum, and its ventral structure. After genera identification of collected ticks, female adult ticks of each genus had been separated by observing small areas of scutum on the anterior dorsum [20].

\section{Results}


A total 200 cows from different breeds were observed at different areas of Pishin, in which percentage of prevalence was $36 \%$, $24 \%, 18.9 \%, 15.5 \%, 5 \%$ in Sindhi, Sahiwal, Tharparkar, American and Australian breeds of cow respectively. The total prevalence was observed as $29 \%$ in different breeds of the cow as shown in (Table 1).

13 males and 8 females were found to be infested in Sindhi cows, 9 males and 5 females in Sahiwal cows, 6 males and 5 females in Tharparkar cows, 4 males and 5 females in American cow and only 1 female with 2 males were infested in Australian cows as shown in (Fig 1).

A total of 200 cows including (100 males and 100 females) from different breeds of the cow of varying age were observed in which 33 were males and 25 were females as shown in (Table 2).

A total population of different tick species was found to be 443. Hylomma anatolicum was the highly infested tick specie with several 134 which was followed by Hylomma dromedarii (87). The maximum number of males was found in Hylomma anatolicum (117). While the maximum number of females were found Boophilus annulatus (60). The minimum number of males were found in Boophilus annulatus (4) while female in Hylomma truncatum (7).
The total male and female ratio was 1.1:1 as shown in (Table 3 ).

The maximum number of Larvae were found in Hylomma anatolicum (37), while the maximum number of nymphs and adults were found in Hylomma anatolicum as 27 and 71. The minimum number of Larvae was found in Hylomma truncatum (7) while Nymphs were found in Hylomma truncatum (3) and the Adult was found in Hylomma scupense and Dermacentor andaroni (9) as shown in (Table 4).

The maximum number of the cow was found to be infested by tick infection in the summer season (N: 133). A total of 238 ticks were collected in summer. The infestation was highest in July (N: 56), which was followed by June (N: 50). The minimum infestation was noted in the winter season in which only 2 cows were found to be infested with a total of 7 ticks as shown in (Table 5).

A total of 443 ticks were observed in different breeds of cows at various parts of the body. 202 ticks were found in ear region, 122 were captured from the mammary gland, 61 from a genital organ, 39 from the tail, and 19 from abdomen and body. Prevalence was $45.59 \%, 27.53 \%, 13.76 \%$, 8.80 , and $4.28 \%$ in the ear, mammary gland, genital organ, body region, and tail respectively as shown in (Table 6).

Table 1. Prevalence of Ixodidae ticks in different breeds of the cow at a different area of Pishin, District

\begin{tabular}{|c|c|c|c|c|c|}
\hline Breeds of cow & Observed & Infested (\%) & Prevalence*(\%) & Male & Female \\
\hline Sindhi & 60 & $21(36)$ & 35 & 11 & 10 \\
Sahiwal & 50 & $14(24)$ & 28 & 5 & 9 \\
Tharparkar & 20 & $11(18.9)$ & 55 & 9 & 2 \\
American & 30 & $9(15.5)$ & 30 & 6 & 3 \\
Australian & 40 & $3(5)$ & 7.5 & 2 & 1 \\
\hline Total & $\mathbf{2 0 0}$ & $\mathbf{5 8 ( 1 0 0 )}$ & $\mathbf{2 9}$ & $\mathbf{3 3}$ & $\mathbf{2 5}$ \\
\hline
\end{tabular}

*Prevalence: $\mathrm{n} / \mathrm{N} ; \mathrm{n}=$ Animals infested by ticks, $\mathrm{N}=$ Total Observed animals 


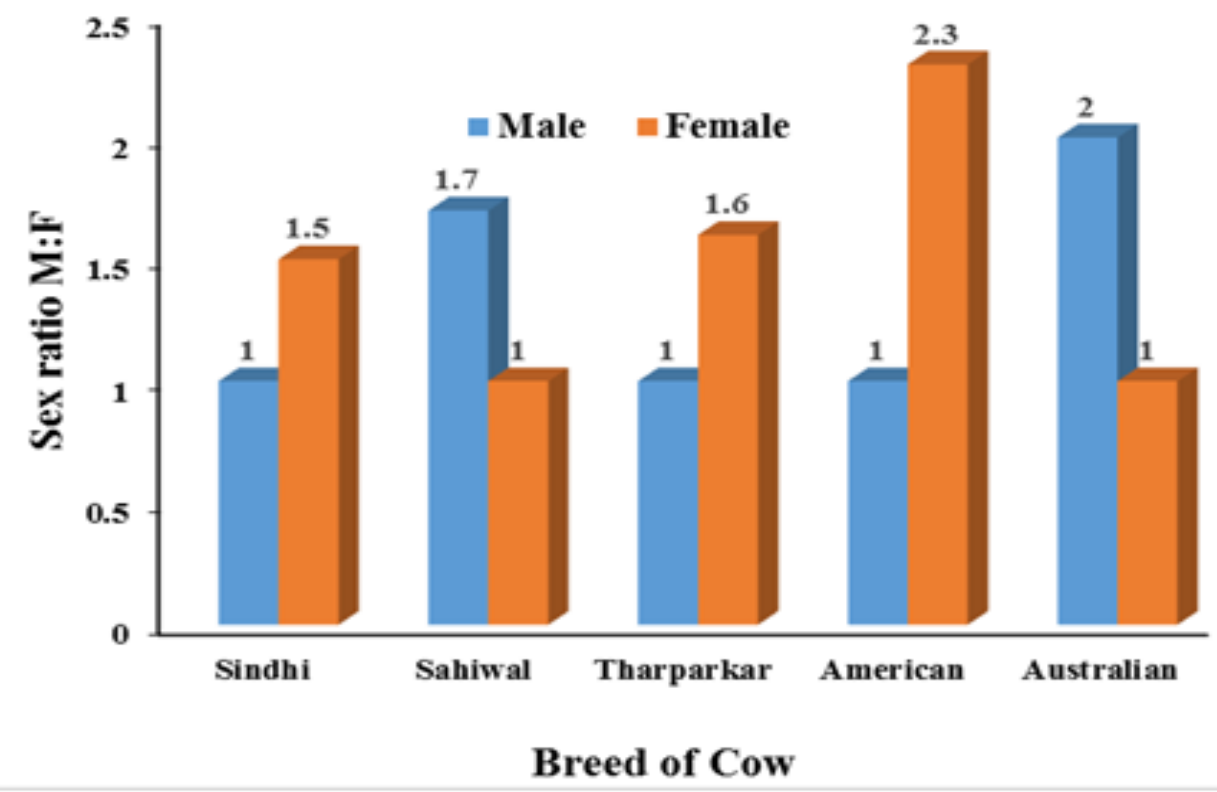

Figure 1. Sex wise ratio of infested host species

Table 2. Total sex-wise distribution and Prevalence of tick infestation

\begin{tabular}{|c|c|c|c|c|c|c|c|c|c|}
\hline \multirow[b]{2}{*}{ Age of cow } & \multicolumn{3}{|c|}{ Observed } & \multicolumn{3}{|c|}{ Infested } & \multicolumn{3}{|c|}{ Prevalence* } \\
\hline & $\stackrel{\widetilde{T}}{\stackrel{\sigma}{\theta}}$ & $\frac{0}{\tilde{J}}$ & & $\stackrel{\sigma}{0}$ & $\frac{0}{\tilde{J}}$ & 思 & 远 & $\underbrace{\stackrel{8}{8}}_{\dot{\Sigma}}$ & $\underbrace{8}_{i}$ \\
\hline$\leq 3$ month & 41 & 21 & 20 & 10 & 8 & 2 & 24.39 & 38.09 & 10 \\
\hline$\leq 1$ year & 73 & 50 & 23 & 19 & 11 & 8 & 26.02 & 22 & 34.78 \\
\hline$\leq 3$ year & 86 & 29 & 57 & 29 & 14 & 15 & 33.72 & 48.27 & 26.31 \\
\hline Total & 200 & 100 & 100 & 58 & 33 & 25 & 29 & 33 & 25 \\
\hline
\end{tabular}

*Prevalence: $\mathrm{n} / \mathrm{N} ; \mathrm{n}=$ Animals infested by ticks, $\mathrm{N}=$ Total Observed animals

Table 3. Total Population of different tick species

\begin{tabular}{|c|c|c|c|}
\hline Tick specie & Tick Population & Percentage \% & M: F ratio \\
\hline Hylomma anatolicum & 134 & 30.24 & $6.5: 1$ \\
Hylomma dromedarii & 87 & 19.63 & $4.8: 1$ \\
Hylomma scupense & 25 & 5.64 & $2.1: 1$ \\
Hylomma truncatum & 17 & 3.83 & $1.4: 1$ \\
Dermacentor andaroni & 22 & 4.96 & $1: 2.1$ \\
Dermacentor variabilis & 52 & 11.73 & $1: 5.5$ \\
Boophilus annulatus & 64 & 14.44 & $1: 5.8$ \\
Amblyomma americanum & 41 & 9.25 & $1: 15$ \\
\hline Total & $\mathbf{4 4 3}$ & $\mathbf{1 0 0}$ & $\mathbf{1 . 1}$ \\
\hline Tick Burden/ Animal & $\mathbf{7 . 6 3}$ & & \\
\hline
\end{tabular}


Table 4. The total number of ticks in the following life stage

\begin{tabular}{|c|c|c|c|}
\hline Tick specie & Larvae & Nymph & Adult \\
\hline Hylomma anatolicum & 37 & 27 & 71 \\
Hylomma dromedarii & 31 & 19 & 35 \\
Hylomma scupense & 7 & 17 & 9 \\
Hylomma truncatum & 3 & 3 & 5 \\
Dermacentor andaroni & 8 & 5 & 9 \\
Dermacentor variabilis & 14 & 14 & 24 \\
Amblyomma americanum & 7 & 9 & 25 \\
Boophilus annulatus & 19 & 11 & 34 \\
\hline Total & $\mathbf{1 2 6}$ & $\mathbf{1 0 5}$ & $\mathbf{2 1 2}$ \\
\hline
\end{tabular}

Table 5. Seasonal activity of ixodid ticks in different areas of Pishin, District

\begin{tabular}{|c|c|c|c|}
\hline Season & Month & No of infested cows & No. of ticks \\
\hline \multirow{4}{*}{ Spring } & March & 9 & 13 \\
& April & 15 & 43 \\
& May & 19 & 69 \\
& Total & $\mathbf{4 3}$ & $\mathbf{1 2 5}$ \\
\hline \multirow{4}{*}{ Summer } & June & 50 & 71 \\
& July & 56 & 134 \\
& August & 27 & 33 \\
& Total & $\mathbf{1 3 3}$ & $\mathbf{2 3 8}$ \\
\hline \multirow{5}{*}{ Autumn } & September & 12 & 45 \\
& October & 6 & 20 \\
& November & 4 & 8 \\
& Total & $\mathbf{2 2}$ & $\mathbf{7 3}$ \\
\hline \multirow{3}{*}{ Winter } & December & 1 & 5 \\
& January & 0 & 2 \\
& February & $\mathbf{2}$ & 0 \\
& Total & $\mathbf{2 0 0}$ & $\mathbf{7}$ \\
\hline
\end{tabular}

Table 6. Distribution of ticks in various body parts of cows

\begin{tabular}{|c|c|c|}
\hline Location & No. of ticks & Percentage (\%) \\
\hline Ear & 202 & 45.59 \\
Mammary gland & 122 & 27.53 \\
Genital organ & 61 & 13.76 \\
Tail & 39 & 8.80 \\
Body & 19 & 4.28 \\
\hline Total & $\mathbf{4 4 3}$ & $\mathbf{1 0 0}$ \\
\hline
\end{tabular}

\section{Discussion}

Ticks are the main source of diseases in livestock. Ticks are responsible for massive economic loss either by transmitting diseases through blood or by causing anemia through bloodsucking. Cattle are more susceptible to tick infestation than other animals [21].
The present study described that the prevalence was observed as $29 \%$ in different breeds of cows. Many researchers reported a higher prevalence of $45.28 \%, 21.67 \%$, $18.33 \%$ \& $7.5 \%$ for cattle, buffalo, sheep, and donkey, respectively [21]. The study's results were also similar to the present study [22]. A very high prevalence of tick 
infestation was observed in Pishin, which might be due to the topographical dissimilarities, and the weather conditions which may favor the growth of the ticks.

Maximum prevalence was found in adult cows ( $\leq 3$ years) as $33.72 \%$, while in calves ( $\leq 3$ months and $\leq 1$ year), the prevalence was approximately equal as $24.39 \%$ and $26.02 \%$ respectively. The observed tick burden/Animal in Pishin was $7.63 \%$. Different researchers found higher tick infestation in adult cows (60.8\%) than calves (20\%) in Oshnavich [23]. The percentage of tick infestation in young cattle was lower than the adult cattle. The different studys opposed this idea as they concluded that ticks prefer young animals due to their tender skin which makes sucking of blood easy for ticks [24-26].

The maximum numbers of cows were found to be infested by tick infection in the summer season (N: 133). A total of 238 ticks were collected in summer. The infestation was highest in July (N: 56), which is followed by June ( $\mathrm{N}$ : 50). The minimum infestation was noted in the winter season in which only 2 animals were found to be infested with a total of 7 ticks. Who noted the highest peak of infestation in July $(57.3 \%)$. In the meantime, the infestation rate was observed a minimum in November as $36.4 \%$. The study of the different researchers also confirmed our results [27, 28].

A total of 443 number of ticks were observed in different breeds of a cow at various parts of the body. Prevalence was $45.59 \%, 27.53 \%, 13.76 \%, 8.80$, and $4.28 \%$ in the ear, mammary gland, genital organ, tail, and the body region of cows respectively. The study results described the face and ears of the host as the most advantageous predilection site for ticks with a prevalence of $62 \%$, whereas they also been found on udder, scrotum, tail, leg, and belly in cattle [14].
Eight species of ticks were identified in the study area including Hylomma anatolicum, Hylomma dromedarii, Hyalomma truncatum, Hylomma scupense, Boophilus annulatus, Dermacentor andaroni, Dermacentor variabilis, Amblyomma Americanum. Hylomma anatolicum, was the most abundant species of tick, infesting cows followed by Boophilus annulatus. Hylomma truncatum was the lowest in numbers, followed by Dermacentor variabilis and Hyalomma scupense. In most breeds of cow, the infestation of $H$. anatolicum was found to be maximum. In research [29] on 740 sheep and goats, the most abundant species were found to be Ripicephalus and Hyalomma. Also, there was another research done in Kerman, which showed that the major kind of ticks is Hyalomma [30]. The male: female ratio was 1.1:1.

\section{Conclusion}

The present research trial revealed a high prevalence of tick infestation in cows and their significant relationship with age and sex in District, Pishin. Unsatisfactory veterinary amenities, optimum climate for tick growth, lack of awareness about the influences of ticks, and lack of systematized controlling techniques could be the reasons for this high prevalence in Pishin, District.

\section{Authors' contributions}

Conceived and designed the experiments: $\mathrm{K}$ Iqbal, N Rafique \& A Karim, Performed the experiments: A Ijaz, MK Taj, A Kakar \& Z Hanif, Analyzed the data: S Bibi \& G Ghafoor, Contributed materials/ analysis/ tools: A Ghafoor, M Shafiq Wrote the paper: K Iqbal.

\section{References}

1. Minjauw B \& McLeod A (2003). Tickborne diseases and poverty: the impact of ticks and tick-borne diseases on the livelihoods of small-scale and marginal livestock owners in India and eastern and southern Africa. Centre for 
Tropical Veterinary Medicine. Edinburgh, UK 124pp.

2. Kilpatrick HJ \& LaBonte AM (2007). Managing urban deer in Connecticut: a guide for residents and communities. Connecticut Department of Environmental Protection, Bureau of Natural Resources-Wildlife Division.

3. Riaz M, Taswar Z \& Zaka Ullah $M$ (2017). An epidemiological survey on diversity and seasonal distribution of hard ticks in sheep and goats in Multan, Pakistan. J Bio Env Sci 1: 50-61.

4. Urquhart GM, Arm our J, Duncan JL, Dunn AM \& Jennings FW (1996). The laboratory diagnosis of parasitism. Vet Parasitol 2: 4-11.

5. Noor J, Ahaduzzaman M, Hossain MMA, Sarker M S \& Rahim SA (2016). Prevalence and morphological identification of tick species infestation in a goat in Chittagong, Bangladesh. Res Rev J vet Sci 2: 42-46.

6. Yakhchali M \& Hasanzadehzarza HS (2004). Study on some ecological aspects and prevalence of different species of hard ticks Acarina: Ixodidae on cattle, buffalo, and sheep in Oshnavieh suburb. PajouheshvaSazandegi, In Animal and Fisheries Sci 63: 30-5.

7. Bayu K (2005). Standard veterinary laboratory diagnostic manual. Vol. III. MOA Addis Ababa.

8. Aydin MF, Aktas M \& Dumanli N (2015). Molecular identification of Theileria and Babesia in ticks collected from sheep and goats in the Black Sea region of Turkey. Para Res 1: 65-69.

9. Parola P \& Raoult D (2001). Ticks and tickborne bacterial diseases in humans: an emerging infectious threat. Clin Infect Dis 32(6): 897-928.

10. Sajid MS, Iqbal Z, Shamim A, Siddique RM, Jawad ul Hussan \& Rizwan HM (2017). Distribution and abundance of ticks infesting livestock population along Karakorum highway from Mansehra to Gilgit, Pakistan. Vet Med Sci 1:051-058.

11. Razmi GR, Glinsharifodini M \& Sarvi S (2007). Prevalence of ixodid ticks on cattle in Mazandaran province, Iran. Korean J Para 4: 307.

12. Sajid MS (2007). Epidemiology, acaricidal resistance of tick population infesting domestic ruminants. Ph.D. thesis. Deptt. of Veterinary Parasitology, Univ of Agri, Pakistan.

13. Kabir MHB, Mondal MMH, Eliyas M, Mannan MA, Hashem MA, Debnath NC \& Elahi MF (2011). An epidemiological survey on investigation of tick infestation in cattle at Chittagong District, Bangladesh. Afri $J$ Micro Res 4: 346-352.

14. Rafique N, Kakar A, Iqbal A, Masood Z \& Razzaq W (2015). Identification of three species of ticks Hylomma anatolicum anatolicum, Hylomma aegyptium and Dermacentor andersoni in Quetta city of Balochistan, Pakistan. Global Vet 6: 842-847.

15. Larry SR \& John JJ (2010). Foundation of Parasitology $8^{\text {th }}$ Ed. Florida International University.

16. Rehman A, Nijhof AM, Sauter-Louis C, Schauer B, Staubach C \& Conraths FJ (2017). Distribution of ticks infesting ruminants and factors associated with high tick prevalence in livestock farms in the semi-arid and arid agroecological zones of Pakistan. Para \& Vect 1: 190.

17. Maidala A (2015). A survey of cattle, sheep, and goat tick infestation in Katagum local government area of Bauchi State, Nigeria. Jaer Issn 1: 2489-0081.

18. Sultana N, Shamim A, Awan M, Ali U, Hassan \& Siddique R (2015). First pilot study on the prevalence of tick 
infestation in livestock of Tehsil, Rawalakot, Azad Kashmir. Adv Anim Vet Sci 3: 430-4.

19. Ghalib SA, Jabbar A, Khan AR \& Zehra A (2010). Current status of the mammals of Balochistan. Pak J Zool 2: 117.

20. Walker AR, Bouattour A, Estrada-pena A, Horak IG, Latif AA, Pegram RG \& Preston PM (2003). Tick of domestic animal in Africa, Guide to Identification, Tick Species. Bioscience Reports, 42 Coniston Drive, Edinburgh EH10 5QR, Scotland, U.K, pp 3-210.

21. Gedilu M, A Mohamed \& Kechero Y (2014) Determination of the prevalence of ixodid ticks of cattle breeds, their predilection sites of variation, and tick burden between different risk factors in BahirDar, Ethiopia. Glob Vet 4: 520529.

22. Abunna F, Tura J and Regassa A (2012). Status of tick infestation in small ruminants of Bedelle district, Oromia region, Ethiopia. Global Vet 5: 459-462.

23. Pawlos W \& Derese D (2013). Study on prevalence and identification of ticks in Humbo district, Southern Nations Nationalities, and People's Region (SNNPR), Ethiopia. J Vet Medi Ani Heal 3: 73-80.

24. Lehmann T (1993). Ectoparasites: direct impact on host fitness. Para Tod 1: 813.

25. Mattioli RC, Dampha K, Bah M, Verhulst A \& Pandey VS (1998). Effect of controlling natural field-tick infestation on the growth of N'Dama and Gobra zebu cattle in the Gambia. Pre Vet Med 3: 137-146.

26. Pegram RG, Lemche J, Chizyuka HGB, Sutherst RW, Floyd RB, Kerr JD \& McCosker PJ (1989). Effect of tick control on liveweight gain of cattle in central Zambia. Med and Vet Ent 3: 313-320.

27. Tadesse F, Abadfaji G, Girma S, kumsa B, Jibat T (2012). Identification of tick species and their preferred site on cattle's body in and around Mizan Teferi, Southwestern Ethiopia. J Vet Med and Ani Hea 1:1-5.

28. Islam MK, Alim MA, Tsuji N \& Mondal, MMH (2006). An investigation into the distribution, host-preference, and population density of ixodid ticks affecting domestic animals in Bangladesh. Trop Ani Hea and Prod 6: 485-490.

29. Nisa KE \& Pour VA (2005). Surveys of sheep and Goat Ticks in Savajbulagh and Abic Area. Abstract Book $5^{\text {th }}$ National Iranian Congress of Parasitology 15-17 November, Tehran, pp: 178.

30. Radfar MH (2005). Evaluation of Ticks Infestation in Cattle, Sheep, goat and Camels in South East Iran, (Keman). Abstract Book $5^{\text {th }}$ National Iranian Congress of Parasitology 15-17 November, Tehran, pp. 193. 